\title{
Peran Kepemilikan Manajerial dalam Memoderasi Pengaruh Profitabilitas, Leverage, Ukuran Perusahaan, Kebijakan Dividen Terhadap Manajemen Laba pada Perusahaan BUMN
}

\author{
Naomi Puspita Sari', Muhammad Khafid ${ }^{2}$ \\ ${ }^{1,2}$ Jurusan Akuntansi, Fakultas Ekonomi, Universitas Negeri Semarang \\ e-mail: ${ }^{1}$ naomipuspitasari@gmail.com, ${ }^{2}$ muh_khafid@mail.unnes.ac.id

\begin{tabular}{ccc}
\hline Diterima & Direvisi & Disetujui \\
$30-06-2020$ & $22-09-2020$ & $28-09-2020$ \\
\hline
\end{tabular}

\begin{abstract}
Abstrak - Laporan keuangan sebagai media penghubung antara manajemen dengan pemilik merupakan sumber informasi penting sehingga harus bersifat andal dan relevan. Akan tetapi, laporan keuangan rawan dipermainkan oleh manajemen dan dapat menyesatkan penggunanya. Manajemen dapat mengintervensi laporan keuangan untuk memenuhi tujuan tertentu dengan melakukan manajemen laba. Penelitian ini bertujuan untuk menganalisis dan memperoleh bukti empiris mengenai pengaruh profitabilitas, leverage, ukuran perusahaan dan kebijakan dividen terhadap manajemen laba dengan dimoderasi kepemilikan manajerial. Populasi dalam penelitian ini adalah perusahaan BUMN yang terdaftar di Bursa Efek Indonesia tahun 2016-2018. Pengambilan sampel menggunakan metode purposive sampling dan menghasilkan 39 unit analisis. Teknik analisis data untuk menguji hipotesis menggunakan moderated regression analysis dengan software IBM SPSS Statistics 21. Hasil penelitian menunjukkan bahwa leverage berpengaruh negatif dan signifikan terhadap manajemen laba. Profitabilitas, ukuran perusahaan dan kebijakan dividen tidak berpengaruh signifikan terhadap tindakan manajemen laba. Penelitian ini menemukan kepemilikan manajerial dalam perusahaan BUMN mampu memoderasi pengaruh leverage terhadap manajemen laba.
\end{abstract}

Kata Kunci: Determinan Manajemen Laba

\begin{abstract}
Financial statements as a communication media between management and owners is an important source of information that must be reliable and relevant. However, financial statements are prone to be played by management and can mislead users. Management can intervene financial statements to achieve their certain goals by using earning management. This study aims to analyze the effect of profitability, leverage, company size and dividend policy on earnings management with managerial ownership as a moderating variable. The population in this study are BUM companies listed on the Indonesia Stock Exchange in 2016-2018. Samples on this research were taken using purposive sampling method and resulted 39 units of analysis. Data analysis techniques to support the hypothesis using moderated regression analysis with IBM SPSS Statistics 21 software. The results showed that the leverage was negative and significant to earnings management. Profitability, company size and dividend policy do not significantly influence earnings management. This study found managerial ownership in BUMN companies can moderate the effect of leverage on earnings management.
\end{abstract}

Keywords: Determinant of Earnings Management

\section{PENDAHULUAN}

Peraturan Otoritas Jasa Keuangan Nomor 29/POJK.04/2016 mengatur bagi perusahaan go public di Indonesia untuk wajib memberikan informasi terkait kegiatan perusahaan dalam bentuk laporan tahunan (annual report). Salah satu kompenen dari laporan tahunan yaitu laporan keuangan. Laporan keuangan merupakan sumber informasi bagi investor terkait posisi keuangan, kinerja keuangan, dan aruskas entitas yang bermanfaat dalam pembuatan keputusan ekonomi (PSAK No. 1 Tentang Laporan Keuangan Revisi 2015).
Laporan keuangan sebagai media penghubung antara manajemen dengan pemilik, rawan dipermainkan oleh manajemen dan dapat menyesatkan bagi para pengguna laporan keuangan. Hal ini dikarenakan manajemen selaku pengelola perusahaan memiliki kebebasan untuk memilih dan menggunakan metode akuntansi dalam menyusun laporan keuangan. Tindakan dimana manajemen melakukan upaya untuk mengintervensi atau mempengaruhi informasi dalam laporan keuangan dengan tujuan mengelabuhi stakeholder yang ingin mengetahui kinerja dan kondisi perusahaan dikenal dengan manajemen laba (Sulistyanto, 2008). 
Manajemen laba menurunkan nilai informasi dalam laporan keuangan yang membantu komunikasi di antara investor, pemegang saham dan publik. Praktik manajemen laba merusak nilai informasi yang mengarahkan pengguna laporan keuangan ke keputusan ekonomi yang tidak akurat. Hal ini berdampak pada keandalan dan kredibilitas informasi akuntansi yang tersaji pada laporan keuangan (Selahudina et al., 2014).

Beberapa kasus yang terjadi membuktikan tindakan manipulasi laba tidak hanya merugikan para pemegang saham, namun juga dapat menjadi bumerang bagi perusahaan. Seperti yang terjadi pada maskapai unggulan Indonesia yakni, Garuda Indonesia yang menunjukkan adanya kejanggalan dalam laporan keuangannya pada tahun 2018. Setelah mencatatkan kerugian pada beberapa tahun terakhir tiba-tiba pada tahun 2018 mengalami laba yang signifikan sebesar US\$ 5,01 juta (Fauzia, 2019). Hal ini lantas ditolak oleh dua komisarisnya, yaitu Chairal Tanjung dan Doni Oskaria. Setelah diusut, ternyata keuntungan Garuda itu didapat dari kontrak kerja sama penyediaan layanan konektivitas wifi dalam penerbangan dan hiburan pesawat dari PT Mahata Aero Teknologi. Akan kejadian tersebut OJK memberikan sanksi untuk GIAA melakukan restatement atas laporan keuangan tahunan per 31 Desember 2018. Hasil penyajian ulang tersebut, mencatatkan Garuda Indonesia rugi bersih sebesar US\$ 175,02 juta atau setara Rp 2,45 triliun dari sebelumnya laba sebesar US\$ 5,01 juta. Penyajian kembali LK GIAA per 2018 berdampak pada harga saham GIAA yang turun sebesar 3,47\% (Hps, 2019).

Penelitian terdahulu menemukan beberapa faktor yang mampu mempengaruhi tindakan manajemen laba dan menampilkan hasil yang beragam. Salah satu faktor yang mempengaruhi manajamen laba adalah profitabilitas. Terdapat perbedaan hasil terkait pengaruh profitabilitas terhadap manajamen laba. Seperti pada penelitian (Lestari \& Murtanto, 2017) yang menunjukkan profitabilitas berpengaruh positif signifikan terhadap manajemen laba. Sementara (Wiyadi et al., 2015) dan (Qallap et al., 2014) memperoleh profitabilitas tidak memiliki pengaruh signifikan pada manajemen laba. Perbedaan hasil penelitian juga terjadi pada variabel leverage, pada penelitian (Lestari \& Murtanto, 2017) menemukan leverage berpengaruh negatif signifikan terhadap manajemen laba. Akan tetapi (Hasty \& Herawaty, 2017) dan (Qallap et al., 2014) memperoleh hasil positif dan signifikan. Namun (Wiyadi et al., 2015) dan (Wirawati et al., 2018) menemukan leverage tidak signifikan terhadap manajemen laba.

Variabel ukuran perusahaan terhadap manajemen laba juga masih inkosisten, seperti penelitian (Lestari \& Murtanto, 2017) memperoleh hasil ukuran perusahaan negatif signifikan. Sedangkan (Fandriani \& Tunjung, 2019) menemukan ukuran perusahaan tidak signifikan terhadap manajemen laba. Pada kajian variabel kebijakan dividen mengalami inkonsistensi hasil pada penelitian terdahulu. Seperti penelitian oleh (Putri, 2012) dan (Dahayani et al., 2017) yang membuktikan kebijakan dividen berpengaruh signifikan terhadap manajemen laba. Sementara (Wirawati et al., 2018) menemukan kebijakan dividen tidak berpengaruh terhadap manajemen laba.

Hasil yang tidak konsisten tersebut membuat peneliti tertarik untuk mengkaji ulang variabel profitabilitas, leverage, ukuran perusahaan dan kebijakan dividen terhadap manajemen laba. Inkonsistensi penelitian terdahulu mengindikasikan perlunya variabel yang mampu memberikan pengaruh memoderasi (memperkuat atau memperlemah) sehingga dapat memberikan referensi mengapa terjadinya inkonsistensi tersebut. Oleh karena itu, peneliti menghadirkan variabel kepemilikan manajerial sebagai variabel yang diduga mampu memoderasi pengaruh profitabilitas, leverage, ukuran perusahaan dan kebijakan dividen terhadap manajemen laba. Dengan demikian, tujuan dari penelitan ini untuk menganalisis pengaruh profitabilitas, leverage, ukuran perusahaan dan kebijakan dividen terhadap manajemen laba dengan dimoderasi variabel kepemilikan manajerial.

Orisinilitas pada penelitian ini yaitu hadirnya kepemilikan manajerial yang diharapkan mampu menjelaskan inkonsistensi pengaruh profitabilitas, leverage, ukuran perusahaan dan kebijakan dividen terhadap manajemen laba. Berdasarkan penelitian terdahulu kepemilikan manajerial cenderung memiliki pengaruh yang konsisten terhadap manajemen laba. Penelitian oleh (Hasty \& Herawaty, 2017); (Lestari \& Murtanto; 2017); (Aljana \& Purwanto, 2017); (Purnama, 2017) mendokumentasikan kepemilikan manajerial berpengaruh negatif signifikan terhadap manajemen. Hal tersebut menjadi pertimbangan penulis dalam menggunakan variabel kepemilikan manajerial sebagai variabel moderating.

Penelitian ini didasarkan pada teori agensi dan teori sinyal. Teori agensi yang dikemukakan oleh (Jensen \& Meckling, 1976) menerangkan hubungan antara prinsipal dan agen, dimana terdapat pemisahan antara kepentingan pemilik perusahaan dan manajer atau pengelola perusahaan dalam menjalankan tugasnya. Permasalahan antara agen dan prinsipal muncul ketika kedua belah pihak mempunyai kepentingan tersediri untuk memenuhi utilitas masing-masing. Manajemen memiliki informasi yang lebih akurat dibanding prinsipal, sehingga ada kemungkinan manajemen berbuat oportunistik salah satunya dengan melakukan manajemen laba. Teori lain yang digunakan pada penelitian ini yaitu signalling theory. Teori ini dikemukakan oleh (Ross, 1977) yang mengungkapkan bahwa pihak internal perusahaan memiliki informasi yang lebih baik mengenai kondisi perusahaan sehingga akan terdorong untuk mempublikasikan informasi tersebut 
untuk menarik para calon investornya agar berkenan menanamkan modalnya sehingga nantinya akan mempengaruhi peningkatan harga saham dari perusahaan tersebut. Semakin banyak informasi yang dipublikasi akan membuat asimetri informasi menjadi lebih kecil.

Profitabilitas merupakan rasio untuk mengukur kemampuan perusahaan dalam menghasilkan laba yang berasal dari operasional perusahaan. Laba sering dikaitkan dengan kinerja suatu perusahaan. Apabila laba perusahaan tinggi diasumsikan bahwa kinerja perusahaan tersebut baik, namun sebaliknya jika laba perusahaan tersebut rendah berarti kinerja perusahaan dianggap jelek. Investor lebih tertarik pada perusahaan dengan profitabilitas yang tinggi, selain itu jika manajemen mampu mencapai target akan mendapatkan apresiasi dari pemilik perusahaan. Umumnya apresiasi ini diberikan dalam bentuk insentif dan bonus sebagai feedback atas kinerja manajemen. Menurut (Sulistiawan et al., 2011) salah satu motivasi tindakan manajemen laba yaitu motivasi bonus.

Berdasarkan teori agensi terdapat masalah keagenan antara manajemen dengan pemilik perusahaan karena masing-masing pihak ingin memaksimalkan utilitasnya. Adanya asimetri informasi memberikan kesempatan manajer untuk bertindak oportunistik ketika dihadapkan pada situasi yang tidak mendukung. Penelitian oleh (Hasty \& Herawaty, 2017) dan (Purnama, 2017) menunjukkan adanya pengaruh positif antara profitabilitas terhadap manajemen laba.

\section{$\mathrm{H}_{1}$ : Profitabilitas berpengaruh positif signifikan terhadap manajemen laba.}

Leverage merupakan rasio pengelolaan hutang yang mencerminkan seberapa besar operasional perusahaan dibiayai menggunakan hutang. Kreditur melihat leverage sebagai tingkat keamanan dalam mengembalikan dana pinjaman jika perusahaan tersebut dilikuidasi. Semakin tinggi rasio leverage semakin tinggi risiko perusahaan dalam membayar kewajibannya.

Merujuk pada teori sinyal, dimana perusahaan memiliki informasi yang lebih baik mengenai kondisi perusahaan yang dikelolanya dan akan terdorong untuk mempublikasikan informasi tersebut untuk menarik para calon investornya (Ross, 1977). Leverage dapat menjadi sinyal untuk menggambarkan kemampuan perusahaan dalam melunasi hutangnya baik jangka panjang ataupun jangka pendek. Sehingga tingkat leverege yang tinggi diduga akan memiliki pengaruh negatif terhadap manajemen laba. Hal dikarenakan kreditur akan memberikan pengawasan yang tinggi untuk perusahaan yang berisko tinggi. Agar kreditur mendapatkan kepercayaan bahwa perusahaan tidak akan dilikuidasi dan mampu membayar hutanghutangnya. Hasil penelitian (Lestari \& Murtanto,
2017) dan (Dewi \& Wirawati, 2019) menunjukkan bahwa leverage berpengaruh negatif signifikan terhadap manajemen laba.

\section{$\mathrm{H}_{2}$ : Leverage berpengaruh negatif signifikan terhadap manajemen laba.}

Ukuran perusahaan merupakan nilai yang menunjukkan besar kecilnya sebuah perusahaan. Perusahaan yang berukuran besar memiliki informasi yang lebih luas dibanding dengan perusahaan kecil sehingga ketersediaan informasi pada perusahaan besar lebih tinggi. Sejalan dengan teori sinyal yang dikenalkan oleh (Ross, 1977) menjelaskan manajemen akan terdorong untuk mempublikasikan informasi yang dimiliki perusahaan untuk menarik para investor. Sehingga ketimpangan informasi akan turun dan pihak eksternal akan lebih kritis dalam menyoroti kinerja perusahaan.

Perusahaan besar memiliki pengawasan yang lebih ketat pula terhadap pihak internal perusahaan, sehingga akan memperkecil kesempatan manajemen untuk bertindak berlawanan dengan tujuan perusahaan. Selain itu, perusahaan besar cenderung lebih dikenal publik dan tidak ingin merusak reputasinya. Penelitian oleh (Lestari \& Murtanto, 2017) dan (Purnama, 2017) membuktikan terdapat pengaruf negatif antara ukuran perusahaan terhadap manajemen laba.

\section{H3: Ukuran perusahaan berpengaruh negatif signifikan terhadap manajemen laba.}

Tingginya laba yang dihasilkan perusahaan akan berdampak pada naiknya deviden yang akan dibagikan kepada pemegang saham. Laba yang besar bersamaan dengan tingkat dividen yang tinggi adalah hal yang dicari setiap investor. Hal ini akan menarik minat para investor agar menanamkan modalnya dan berinvestasi pada perusahaan tersebut. Ketidakpastian bahwa manajemen tidak akan berbuat curang dengan bertindak opotunistik dan mengabaikan nilai perusahaan membuat investor lebih menyukai dividen. Sedangkan manajemen lebih memilih untuk menahan laba daripada membagikan dividen. Hal ini karena laba ditahan dapat digunakan untuk melakukan ekspansi perusahaan. Merujuk pada teori agensi dimana terdapat konflik keagenan yang dipicu karena masing-masing pihak ingin memaksimalkan utilitasnya. Sehingga kebijakan dividen diduga memberikan pengaruh positif terhadap manajemen laba. Penelitian terdahulu oleh (Putri, 2012) dan (Dahayani et al., 2017) memberikan bukti empiris bahwa kebijakan dividen memiliki pengaruh terhadap manajemen laba.

\section{H4: Kebijakan dividen berpengaruh positif signifikan terhadap manajemen laba.}

Pemilik perusahaan sebagai prinsipal berharap agen (manajemen) mampu mengelola kekayaanya 
dengan baik dan menghasilkan laba maksimal. Pihak manajemen akan berupaya untuk mencapai target dan menyenangkan hati pemilik sehingga manajemen akan mendapatkan kompensasi bonus yang besar. Teori agensi menjelaskan bahwa terdapat pemisahan tugas antara manajemen (pengelola) dengan pemilik dalam menjalankan kegiatan perusahaan. Hal ini dapat membuat manajemen bertindak oportunistik karena sebagai pengelola ia lebih mengerti kondisi perusahaan. Namun hal itu dapat diminimalisir ketika manajemen juga bertindak sebagai pemilik yang menanamkan modalnya pada perusahaan yang ia kelola.

Adanya kepemilikan saham oleh manajemen atau disebut kepemilikan manajerial akan menyelaraskan kepentingan manajer dengan pemegang saham sehingga mengurangi konflik diantara mereka (Lestari \& Murtanto, 2017). Hal lain yang perlu diperhatikan terkait kepemilikan manajerial adalah rendahnya pengawasan pihak investor, dimana manajer akan lebih leluasa untuk melakukan kecurangan. Manajer yang juga mempunyai saham mempunyai kepentingan pribadi yaitu mengharapkan pengembalian yang diperoleh dari kepemilikan sahamnya pada perusahaan tersebut (Jannah \& Mildawati, 2017). Dengan demikian, manajer memiliki kesempatan untuk melakukan manipulasi laba baik untuk menaikkan laba maupun menurunkan laba.

\section{H5: Kepemilikan manajerial memoderasi secara signifikan pengaruh profitabilitas terhadap manajemen laba.}

Dalam menunjang kegiatan operasional perusahaan dapat menggunakan sumber dana baik dari dalam maupun luar perusahaan. Salah satu sumber pendanaan dari luar perusahaan adalah pinjaman bank. Leverage merupakan alat untuk mengukur seberapa jauh suatu perusahaan bergantung pada kreditur dalam membiayai aset perusahaan (Jannah \& Mildawati, 2017). Tingkat hutang yang berlebihan dapat berakibat fatal pada perusahaan. Kepemilikan manajerial membuat manajer lebih berhati-hati bertindak dan membuat keputusan dikarenakan manajer juga sebagai pemilik saham. Akan tetapi kepemilikan manajerial yang tinggi dapat juga memperlemah pengawasan kepada manajemen. Apabila manajemen tidak memperhatikan tingkat hutang dan tidak diikuti dengan kinerja yang baik, maka perusahaan berpotensi mengalami kebangkrutan yang lebih tinggi.

Sejalan dengan teori agensi oleh (Jensen \& Meckling, 1976) bahwa agen bisa saja bersikap menyimpang dan mengabaikan tujuan perusahaan. Oleh karena itu, ketika manajer berada pada kondisi terdesak baik karena membutuhkan pendanaan atau akibat tingginya leverage dapat memotivasi manajer untuk melakukan praktik manajemen laba dan membuat kinerja perusahaan terlihat tidak buruk.

\section{H6: Kepemilikan manajerial memoderasi secara signifikan pengaruh leverage terhadap manajemen laba.}

Perusahaan besar lebih bertindak hati-hati dalam melakukan pengelolaan perusahaan karena mendapat perhatian dari publik. Investor akan lebih percaya pada perusahaan besar yang memiliki tata kelola perusahaan yang baik. Merujuk pada teori sinyal oleh (Ross, 1977), perusahaan yang besar akan memberi sinyal positif terhadap investor karena dianggap memiliki informasi yang lebih banyak dibandingkan perusahaan kecil. Penting bagi manajemen yang juga mempunyai kepemilikan saham pada perusahaan agar memiliki kesadaran terkait pentingnya legitimasi dari masyarakat dalam hal sosial dan lingkungan yang berkaitan dengan kelangsungan perusahaan jangka panjang. Dengan demikian manajemen tidak akan melakukan tindakan yang melangar norma-norma dan bertindak atas kepentingan perusahaan. Selain itu hadirnya kepemilikan saham akan menurunkan konflik kepentingan antara manajemen dengan pemilik saham seperti yang dijelaskan teori agensi. Membuat perilaku perusahaan untuk menciptakan kebijakan secara sehat demi kemakmuran pemegang saham dan keberlanjutan perusahaan.

\section{H7: Kepemilikan manajerial memoderasi secara signifikan pengaruh ukuran perusahaan terhadap manajemen laba.}

Perusahaan akan dinilai baik oleh investor ketika perusahaan tersebut mampu memberikan dividen yang besar bagi para investornya. Sehingga manajemen akan berusaha untuk memaksimalkan laba yang diperoleh agar tetap mendapatkan kepercayaan investor. Teori agensi menerangkan bahwa terdapat perbedaan informasi antara prinsipal dan agen yang lebih menguntungkan pihak agen. Akan berbeda jika manajemen selaku pengelola usaha juga memiliki saham atas perusahaan yang dikelolanya. Hal ini akan mengurangi konflik kepentingan pada kedua pihak. Namun, disisi lain manajemen yang menanamkan dana pada perusahaan yang dikelolanya juga mengharapkan timbal balik atas investasinya. Manajemen akan cenderung memihak para investor yang selalu menginginkan dividen yang besar. Dalam kondisi seperti itu manajemen dapat termotivasi untuk melakukan manajemen laba tanpa memikirkan keberlanjutan perusahaan.

\footnotetext{
Hs: Kepemilikan manajerial memoderasi secara signifikan pengaruh ukuran perusahaan terhadap manajemen laba.
} 
Berdasarkan kerangka berpikir di atas, berikut model penelitian yang digunakan dalam penelitian ini:

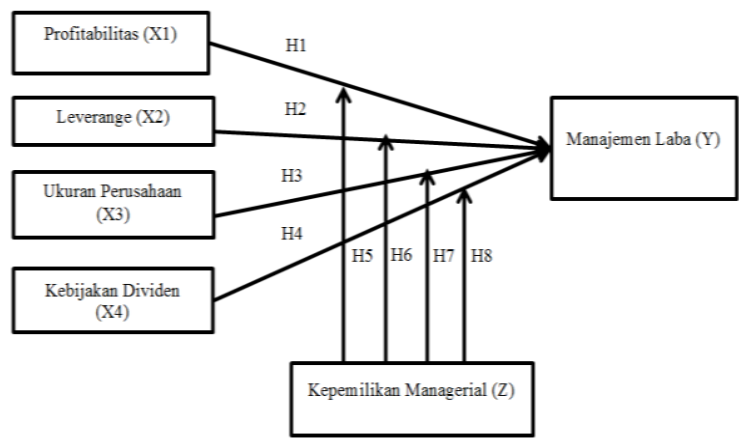

Sumber: Model Penelitian (2020)

Gambar 1. Model Penelitian

\section{METODE PENELITIAN}

Penelitian ini merupakan penelitian kuantitatif dengan menggunakan data sekunder berupa laporan keuangan dan laporan tahunan. Populasi dalam penelitian ini yaitu perusahaan BUMN yang terdaftar di Bursa Efek Indonesia (BEI) tahun 2016-2018. Teknik pengambilan sampel menggunakan metode purposive sampling dengan kriteria yang telah ditentukan sehingga menghasilkan 39 unit analisis. Beberapa kriteria pengambilan sampel dalam penelitian ini disajikan dalam tabel 1 .

Tabel 1. Pengambilan Sampel Penelitian

\begin{tabular}{|c|l|c|}
\hline No & \multicolumn{1}{|c|}{ Kriteria } & Jumlah \\
\hline 1 & Perusahaan BUMN yang terdaftar di BEI & 20 \\
\hline 2 & $\begin{array}{l}\text { Perusahaan yang tidak menyajikan } \\
\text { laporan keuangan dan laporan tahunan } \\
\text { selama periode 2016 s.d 2018 }\end{array}$ & $(0)$ \\
\hline 3 & $\begin{array}{l}\text { Perusahaan yang tidak menyediakan } \\
\text { informasi terkait variabel yang diteliti } \\
\text { selama periode 2016 s.d 2018 }\end{array}$ & $(7)$ \\
\hline 4 & Jumlah sampel yang layak diobservasi & 13 \\
\hline 5 & Periode pengamatan & 3 \\
\hline 6 & Unit Analisis & 39 \\
\hline
\end{tabular}

Sumber: Data Sekunder diolah, 2017

Penelitian ini menggunakan enam variabel penelitian yang terdiri atas satu variabel dependen yaitu manajemen laba, empat variabel independen yaitu profitabilitas; leverage; ukuran perusahaan; kebijakan dividen, serta satu variabel moderating yaitu kepemilikan manajerial. Definisi operasional variabel penelitian disajikan pada tabel berikut:
Tabel 2. Definisi Operasional Variabel Penelitian

\begin{tabular}{|c|c|c|}
\hline Variabel & Definisi & Indikator \\
\hline $\begin{array}{l}\text { Manajemen } \\
\text { Laba }\end{array}$ & $\begin{array}{l}\text { Tindakan yang disengaja oleh } \\
\text { manajemen untuk } \\
\text { mendapatkan laba sesuai apa } \\
\text { yang diingikan manajemen } \\
\text { untuk tujuan tertentu, dalam } \\
\text { batasan yang diperbolehkan } \\
\text { prinsip-prinsip akuntansi } \\
\text { berterima umum. }\end{array}$ & $\begin{array}{l}\text { discretionary accrual (DA) dengan } \\
\text { menggunakan Modified Jones } \\
\text { Model. }\end{array}$ \\
\hline Profitablitas & $\begin{array}{l}\text { Rasio untuk menilai } \\
\text { kemampuan perusahaan dalam } \\
\text { mendapatkan keuntungan. }\end{array}$ & ROA $=\frac{\text { Net Income After Tax }}{\text { Total Asset }}$ \\
\hline Leverage & $\begin{array}{l}\text { Rasio pengelolaan hutang yang } \\
\text { mencerminkan seberapa besar } \\
\text { operasional perusahaan } \\
\text { dibiayai menggunakan hutang } \\
\text { dengan memiliki beban tetap. }\end{array}$ & $D E R=\frac{\text { Total Liabilitas }}{\text { Total Equity }}$ \\
\hline $\begin{array}{l}\text { Ukuran } \\
\text { Perusahaan }\end{array}$ & $\begin{array}{l}\text { Nilai yang menunjukkan besar } \\
\text { kecilnya ukuran sebuah } \\
\text { perusahaan. }\end{array}$ & Firm Size $=$ Ln Total Aset \\
\hline $\begin{array}{l}\text { Kebijakan } \\
\text { Dividen }\end{array}$ & $\begin{array}{l}\text { Keputusan seberapa besar } \\
\text { pembagian laba berupa dividen } \\
\text { kepada para pemegang saham } \\
\text { perusahaan. }\end{array}$ & $D P R=\frac{\text { Diveden per lembar }}{\text { Laba per lembar saham }}$ \\
\hline $\begin{array}{l}\text { Kepemilika } \\
\text { n Manajerial }\end{array}$ & $\begin{array}{l}\text { Kepemilikan saham oleh pihak } \\
\text { manajemen maupun direktur } \\
\text { perusahaan. }\end{array}$ & $\begin{aligned} & \begin{array}{l}\text { Kepemilikan Manajerial } \\
\text { saham milik manajemen }\end{array} \\
= & \frac{\text { total saham yang beredar }}{\text { tot }}\end{aligned}$ \\
\hline
\end{tabular}

Sumber: Ringkasan peneliti, 2020

Teknik pengumpulan data yang digunakan pada penelitian ini adalah teknik dokumenter dengan mengumpulkan laporan keuangan dan laporan tahunan yang diakes melalui situs www.idx.co.id. Pengujian hipotesis dalam penelitian ini menggunakan analisis regresi moderasi dengan uji selisih nilai mutlak. Sebelumnya perlu dilakukan uji asumsi klasik untuk menghasilkan nilai parameter model penduga yang sah dan memenuhi kriteria BLUE (Best Linear Unbiased Estimated). Rumus regresi untuk menguji hubungan antara variabel bebas terhadap manajemen laba dan peran moderasi dari kepemilikan manajerial adalah sebagai berikut:

$M L B=\alpha+\beta 1 R O A+\beta 2 D E R+\beta 3 S I Z E+\beta 4 K D+$ $\beta 5|R O A-K M|+\beta 6|D E R-K M|+\beta 7|S I Z E-K M|+$ $\beta 8|D P R-K M|+\varepsilon$

Keterangan:

MLB = Manajemen Laba

$\alpha \quad=$ Konstanta

$\beta=$ Koefisien Regresi

$\mathrm{ROA}=$ Profitabilitas

DER = Leverage

Size = Ukuran Perusahaan

$\mathrm{KD}=$ Kebijakan Dividen

$\mathrm{KM}=$ Kepemilikan Manajerial

\section{HASIL DAN PEMBAHASAN}

Hasil perhitungan (output) uji statistik deskriptif dengan menggunakan SPSS 21 didapatkan nilai maksimum, minimum, rata-rata dan standar deviasi untuk masing-masing variabel sebagai berikut: 
Tabel 3. Hasil Analisis Deskriptif

\begin{tabular}{|l|c|r|r|r|r|}
\hline \multicolumn{7}{|c|}{ Descriptive Statistics } \\
\hline & N & Minimum & Maximum & Mean & Std. Deviation \\
\hline MLB & 39 & $-0,13183$ & 0,37636 & 0,0997645 & 0,11739389 \\
\hline ROA & 39 & 0,01 & 0,21 & 0,0508 & 0,05355 \\
\hline DER & 39 & 0,45 & 11,06 & 3,3653 & 2,81035 \\
\hline SIZE & 39 & 29,89 & 34,80 & 32,2739 & 1,48937 \\
\hline KD & 39 & 0,15 & 0,90 & 0,3577 & 0,18682 \\
\hline KM & 39 & 0,00000 & 0,00391 & 0,0002734 & 0,00081829 \\
\hline $\begin{array}{l}\text { Valid N } \\
\text { (listwise) }\end{array}$ & 39 & & & & \\
\hline
\end{tabular}

Sumber: Output SPSS, 2020

Dari Tabel 3, manajemen laba dari 39 unit analisis memiliki nilai minimum $-0,13183$ dan nilai maksimum 0,376360. Deviasi standar sebesar 0,11739389 menunjukkan simpangan data yang cukup besar karena nilainya lebih yang lebih tinggi dari mean yaitu 0,0997645. Variabel ROA memiliki nilai rata-rata 0,0508 yang menunjukkan perusahaan sampel hanya mampu menghasilkan keuntungan sebesar 5\% dari aset yang dimiliki. Nilai rata-rata variabel DER sebesar 3,3653 yang artinya perusahaan cukup bergantung pada hutang untuk menjalankan kegiatan operasionalnya.

Variabel SIZE dalam penelitian ini memiliki rentang nilai dari 29,89 sampai 34,80. Rata-rata KD sebesar 0,3577 dan standar deviasi sebesar 0,18682, yang menunjukkan simpangan data cukup baik karena nilai standar deviasi lebih kecil dari rataratanya. Untuk variabel KM memiliki rentang nilai dari 0,00000 sampai 0,00391 dengan nilai rata-rata 0,0002734 dan standar deviasi sebesar 0,00081829.

Model penelitian ini telah lolos uji normalitas menggunakan uji statistik kolmogorov-smirnov. Hal ini terlihat pada tabel berikut:

Tabel 4. Hasil Uji Normalitas

\begin{tabular}{|l|l|r|}
\hline \multicolumn{2}{|c|}{} & $\begin{array}{r}\text { Unstandardized } \\
\text { Residual }\end{array}$ \\
\hline $\mathrm{N}$ & 39 \\
\hline \multirow{2}{*}{ Normal Parameters } & a,b &, 0000000 \\
\cline { 2 - 3 } & Mean &, 09554736 \\
\hline \multirow{2}{*}{$\begin{array}{l}\text { Most Extreme } \\
\text { Differences }\end{array}$} & Absolute &, 098 \\
\cline { 2 - 3 } & Positive &, 067 \\
\cline { 2 - 3 } & Negative &, 098 \\
\hline Kolmogorov-Smirnov Z &, 611 \\
\hline Asymp. Sig. (2-tailed) &, 850 \\
\hline
\end{tabular}

Sumber: Output SPSS, 2020

Nilai signifikan pada Tabel 4 sebesar 0,850 $(0,850>\alpha=0,05)$ yang menunjukkan bahwa model regresi dalam penelitian ini memiliki distribusi data yang normal.

Selanjutnya dilakukan uji asumsi klasik berupa uji multikolinearitas, uji autokorelasi dan uji heterokskedastisitas. Hasil uji multikolinearitas disajikan dalam tabel berikut:
Tabel 5. Hasil Uji Multikolinearitas

\begin{tabular}{|c|c|c|}
\hline \multirow{2}{*}{ Variabel } & \multicolumn{2}{|c|}{ Collinearity Statistics } \\
\hline & Tolerance & VIF \\
\hline ROA & ,214 & 4,684 \\
\hline DER & 340 & 2,939 \\
\hline SIZE & 281 & 3,559 \\
\hline $\mathrm{KD}$ & , 180 & 5,554 \\
\hline $\mathrm{KM}$ & 921 & 1,086 \\
\hline
\end{tabular}

Sumber: Output SPSS, 2020

Tidak terdapat variabel yang terindikasi mengalami multikolinearitas antar variabel independen pada model regresi yang digunakan dalam penelitian karena semua variabel memiliki nilai tolerance $>0,01$ dan memiliki nilai VIF $<10$.

Dalam penelitian ini uji autokorelasi dilakukan dengan menggunakan uji Durbin-Watson (DW). Berikut merupakan hasil dari uji DW:

Tabel 6. Hasil Uji Autokorelasi

\begin{tabular}{|l|c|r|r|r|r|}
\hline Model & R & R Square & $\begin{array}{r}\text { Adjusted } \\
\text { R Square }\end{array}$ & $\begin{array}{l}\text { Std. Error of } \\
\text { the Estimate }\end{array}$ & $\begin{array}{r}\text { Durbin- } \\
\text { Watson }\end{array}$ \\
\hline 1 &, $581^{\mathrm{a}}$ &, 338 &, 237 &, 10253 & 2,176 \\
\hline
\end{tabular}

Sumber: Output SPSS, 2020

Nilai DW hitung pada Tabel 6 sebesar 2,176 dan berada dalam rentang $\mathrm{dU}<\mathrm{d}<4$-dU $(1,7886<2,176<2,2114)$. Sehingga dapat disimpulkan bahwa dari model regresi yang diuji tidak terjadi masalah autokorelasi.

Uji heterokskedastisitas dilakukan dengan menggunakan uji gletser dengan tingkat signifikan 5\%. Hasil uji heterokskedastisitas disajikan pada tabel berikut:

Tabel 7. Hasil Uji Heterokskedastisitas

\begin{tabular}{|l|r|r|r|r|}
\hline \multirow{2}{*}{ Model } & \multicolumn{2}{|c|}{ Unstandardized Coefficients } & \multirow{2}{*}{ t } & \multirow{2}{*}{ Sig. } \\
\cline { 2 - 3 } & \multicolumn{1}{|c|}{$\mathrm{B}$} & \multicolumn{1}{c|}{ Std. Error } & & \\
\hline (Constant) &, 602 &, 355 & 1,698 &, 099 \\
\hline ROA &, 205 &, 383 &, 534 &, 597 \\
\hline DER &, 003 &, 006 &, 504 &, 617 \\
\hline SIZE &,- 017 &, 012 & $-1,424$ &, 164 \\
\hline KD &, 008 &, 120 &, 065 &, 948 \\
\hline KM & 1,126 & 12,082 &, 093 &, 926 \\
\hline
\end{tabular}

Sumber: Output SPSS, 2020

Dari Tabel 7 diketahui bahwa nilai probabilitas signifikansi di atas tingkat kepercayaan $5 \%$ atau 0,05. Sehingga, model regresi dalam penelitian ini tidak mengandung adanya masalah heteroskedastisitas. Dengan demikian, model penelitian telah memenuhi syarat BLUE (Best Linear Unbiased Estimated) dan model regrei layak untuk dilakukan pengujian hipotesis.

Penelitian ini menggunakan moderated regression analysis (MRA) dengan uji selisih nilai 
mutlak untuk menguji hipotesis yang telah diajukan sebelumnya. Hasi uji selisih nilai mutlak disajikan pada tabel berikut:

Tabel 8. Hasil Uji Selisi Nilai Mutlak Sumber: Output SPSS, 2020

\begin{tabular}{|c|c|c|c|c|c|c|}
\hline & \multicolumn{2}{|c|}{$\begin{array}{c}\text { Unstandardized } \\
\text { Coefficients }\end{array}$} & \multirow{2}{*}{$\begin{array}{c}\begin{array}{c}\text { Standardized } \\
\text { Coefficients }\end{array} \\
\text { Beta }\end{array}$} & \multirow[t]{2}{*}{$t$} & \multirow[t]{2}{*}{ Sig. } \\
\hline & & $B$ & Std.Error & & & \\
\hline \multirow{9}{*}{1} & (Constant) & ,044 & ,025 & & 1,774 & ,086 \\
\hline & Zscore: ROA &,- 047 & ,071 &,- 401 &,- 663 &, 512 \\
\hline & Zscore: DER &,- 135 & ,038 & $-1,152$ & $-3,597$ & ,001 \\
\hline & Zscore: SIZE & ,018 &, 030 & , 150 & ,582 &, 565 \\
\hline & Zscore: KD &, 065 & ,041 &, 553 & 1,566 &, 128 \\
\hline & ROA_KM &,- 006 & ,071 &,- 059 &,- 081 & 936 \\
\hline & DER_KM & ,156 & ,041 & 1,382 & 3,816 & 001 \\
\hline & SIZE_KM &,- 054 &, 040 &,- 452 & $-1,360$ &, 184 \\
\hline & KD_KM &,- 035 & ,041 &,- 352 &,- 852 & 401 \\
\hline
\end{tabular}
berikut:

Dari Tabel 8 dapat diinterpretasikan sebagai

\section{Pengaruh Profitabilitas terhadap Manajemen Laba}

Pengujian hipotesis menunjukkan bahwa tingkat signifikan profitabilitas sebesar 0,512 $(0,512>0,05)$ sehingga didapatkan bahwa H1 ditolak. Hal tersebut berarti bahwa upaya manajemen untuk melakukan manajemen laba tidak dipengaruhi oleh profitabilitas. Penelitian ini tidak menunjukkan kesesuaian dengan teori agensi yang diungkapkan diawal dimana seharusnya manajemen akan termotivasi untuk mendapatkan bonus jika ia memiliki kinerja yang baik. Seperti yang diungkapkan (Sulistiawan et al., 2011) bahwa individu atau organisasi dapat termotivasi untuk melakukan tindakan manajemen laba oleh beberapa hal yaitu motivasi bonus, motivasi utang, motivasi pajak, motivasi penjualan saham dan motivasi pergantian direksi. Hal tersebut dapat dimungkinkan karena pada kenyataannya manajer tidak selalu bertindak oportunis untuk memperoleh hasil kinerja yang positif didepan para pemilik perusahaan.

Pemikiran ini didukung oleh stewardship theory yang dikemukakan oleh (Davis et al., 1997) bahwa terdapat hubungan psikologi dan sosiologi dimana manajer adalah sebagai steward akan bertindak sesuai kepentingan pemilik. Dalam teori ini mengasumsikan terdapat hubungan yang kuat antara kesuksesan organisasi dengan kepuasan pemilik yang tampak pada perilaku manajer ketika dihadapkan pada situasi dimana terdapat perbedaan kepentingan antara steward dan pemilik, dimana steward lebih memilih bekerjasama daripada menentangnya (Raharjo, 2007).

\section{Pengaruh Leverage terhadap Manajemen Laba}

Pengujian hipotesis menunjukkan bahwa tingkat signifikan leverage sebesar 0,001 $(0,001<$ $0,05)$ dan Unstandardized coefficients beta leverage sebesar -0,135. Dengan demikian H2 yang menyatakan leverage berpengaruh negatif dan signifikan terhadap manajemen laba, diterima. Hal ini menunjukkan bahwa semakin tinggi rasio leverage akan mengurangi tindakan manajemen dalam melakukan manajemen laba. Leverage merupakan rasio pengelolaan hutang yang menggambarkan seberapa besar perusahaan bergantung pada hutang. Rasio ini akan memberikan sinyal bagi perbankan untuk menilai apakah perusahaan layak untuk mendapatkan pinjaman. Hasil ini sesuai dengan teori sinyal yang menyatakan bahwa perusahaan akan terdorong untuk melaporkan laporan keuangan bagi pihak yang berkepentingan.

Leverage dapat menjadi sinyal untuk menggambarkan kemampuan perusahaan dalam melunasi hutangnya baik jangka panjang ataupun jangka pendek. Sehingga kreditur akan memberikan pengawasan lebih untuk memberikan pinjaman agar kreditur mendapatkan kepercayaan bahwa perusahaan tidak akan dilikuidasi dan mampu membayar hutang-hutangnya. Hasil ini sejalan dengan penelitian (Lestari \& Murtanto, 2017) dan (Dewi \& Wirawati, 2019) yang menemukan leverage berpengaruh negatif signifikan terhadap manajemen laba.

\section{Pengaruh Ukuran Perusahaan terhadap Manajemen Laba}

Pengujian hipotesis menunjukkan bahwa tingkat signifikan ukuran perusahaan sebesar 0,565 $(0,565>0,05)$ sehingga didapatkan bahwa H3 ditolak. Hal tersebut berarti bahwa ukuran perusahaan tidak mampu menjadi prediktor untuk melihat apakah perusahaan melakukan manajemen laba atau tidak. Hasil ini tidak sesuai dengan teori sinyal yang menyatakan perusahaan sebagai pemilik informasi keuangan akan terdorong untuk mempublikasikan informasi tersebut untuk menarik para calon investornya. Banyak nya informasi yang diketahui oleh investor akan membuat investor sadar tentang kondisi suatu perusahaan. Sehingga perusahaan akan lebih berhati-hati dalam melakukan pelaporan keuangan dan cenderung melaporkan kondisi keuangan dengan akurat karena lebih diperhatikan oleh investor.

Tidak adanya pengaruh yang signifikan antara ukuran perusahaan dan manajemen laba karena pada beberapa perusahaan dengan aset yang tinggi ataupun rendah masih melakukan manajemen laba dan beberapa perusahaan lainnya meski memiliki total aset yang tinggi atau rendah perusahaan tersebut tidak berupaya melakukan manajemen laba. Hasil ini konsisten dengan penelitian (Wiyadi et al., 2015) dan (Fandriani \& Tunjung, 2019) yang menyatakan ukuran perusahaan tidak memiliki pengaruh terhadap manajemen laba.

\section{Pengaruh Kebijakan Dividen terhadap Manajemen Laba}


Pengujian hipotesis menunjukkan bahwa tingkat sigifikan kebijakan dividen sebesar 0,128 $(0,128>0,05)$ sehingga didapatkan bahwa $\mathrm{H} 4$ ditolak. Tidak berpengaruhnya kebijakan dividen terhdap manajemen laba diduga karena pengambilan keputusan besarnya dividen yang dibagikan melibatkan pihak prinsipal yang dilakukan pada saat Rapat Umum Pemegang Saham (RUPS), sehingga manajemen tidak bisa mengintervensi besarnya laba yang akan dibagikan. Penelitian ini menunjukkan ketidak sesuaian dengan teori agensi yang diungkapkan diawal dimana seharusnya ketika kebijakan dividen tinggi manajemen akan berupaya melakukan manajemen laba dengan menurunkan labanya karena manajemen lebih suka tidak membagikan dividen dan menahan laba guna kegiatan investasi perusahaan. Hasil penelitian ini sesuai dengan (Wirawati et al., 2018) dan (Hasty \& Herawaty, 2017) yang menemukan kebijakan dividen tidak berpengaruh terhadap manajemen laba.

\section{Kepemilikan Manajerial Memoderasi Pengaruh Profitabilitas terhadap Manajemen Laba}

Pengujian hipotesis menunjukkan bahwa kepemilikan manajerial tidak dapat memoderasi pengaruh profitabilitas terhadap manajemen laba karena nilai sig 0,936 , nilai ini melebihi $\alpha=5 \%$. Sehingga didapatkan bahwa H5, ditolak. Hasil penelitian ini tidak sesuai dengan agency theory, yang mana kepemilikan manajerial tidak mampu mengatasi konflik keagenan yang terjadi. Hasil ini diduga karena besarnya proporsi saham yang dimiliki oleh manajemen sangat kecil. Disisi lain kemampuan manajemen mengelola aset yang baik akan menghasilkan laba yang tinggi, manajemen

akan dinilai memiliki kinerja yang baik. Atas kinerjanya manajemen akan diberikan insentif dan investor akan mendapatkan dividen yang tinggi pula. Hal ini akan mengurangi motivasi manajemen untuk berkeinginan melakukan manajemen laba. Oleh karena itu pada penelitian ini hubungan antara profitabilitas dan manajemen laba tidak dapat dimoderasi oleh kepemilikan manajerial.

\section{Kepemilikan Manajerial Memoderasi Pengaruh Leverage terhadap Manajemen Laba}

Pengujian hipotesis pada Tabel 8 menunjukkan tingkat signifikan interaksi antara leverage dan kepemilikan manajerial sebesar 0,001 $(0,001<0,05)$ dan Unstandardized coefficients beta DER_KM sebesar 0,156. Dengan demikian, H6 yang menyatakan kepemilikan manajerial dapat memoderasi pengaruh leverage terhadap manajemen laba, diterima. Hal ini mengindikasi kepemilikan manajerial dapat memoderasi leverage terhadap manajemen laba secara signifikan dan memiliki arah positif. Sehingga dapat dipahami bahwa kepemilikan manajerial mampu memperlemah hubungan negatif leverage terhadap manajemen laba.
Temuan kepemilikan manajerial mampu memperlemah hubungan leverage terhadap manajemen laba sesuai dengan teori agensi yang telah diungkapkan diawal. Perusahaan dengan ptingkat kepemilikan manajerial tinggi lebih berisiko untuk melakukan tindakan manajemen laba karena rendahnya pengawasan dari pemegang saham. Salah satu motivasi untuk melakukan manajemen laba ialah motivasi utang (Sulistiawan et al., 2011). Agar kreditur mau memberikan suntikan dana, tentunya manajer harus menunjukkan performa yang baik dari perusahaan dan untuk memperoleh pinjaman dari kreditur, perilaku kreatif dari manajer untuk menampilkan performa yang baik dari laporan keuangannya pun seringkali muncul. Hadirnya kepemilikan manajerial yang tinggi akan membuat manajemen berperilaku oportunistik tanpa ada yang mengawasi.

\section{Kepemilikan Manajerial Memoderasi Pengaruh Ukuran Perusahaan terhadap Manajemen Laba}

Pengujian hipotesis menunjukkan bahwa kepemilikan manajerial tidak dapat memoderasi pengaruh ukuran perusahaan terhadap manajemen laba karena nilai sig 0,184 , nilai ini melebihi $\alpha=5 \%$. Sehingga didapatkan bahwa H7, ditolak. Penelitian ini memberikan hasil yang tidak membuktikan agency theory yang mengasumsikan manajer sebagai pengelola dan juga sebagai pemilik yang memiliki saham pada perusahaan akan menghilangkan masalah keagenan. Teori yang tidak dapat dibuktikan tersebut mungkin disebabkan karena, manajer yang memiliki saham perusahaan mempunyai kecenderungan untuk membuat kebijakan mengelola pendapatan dengan mengingat keinginan investor, misalnya dengan meningkatkan pendapatan sehingga banyak investor tertarik dan akan menaikkan harga saham perusahaan (Agustia, 2013). Dengan demikian dapat disimpulkan bahwa kepemilikan manajerial tidak mampu memoderasi hubungan ukuran perusahaan terhadap manajemen laba.

\section{Kepemilikan Manajerial Memoderasi Pengaruh Kebijakan Dividen terhadap Manajemen Laba}

Pengujian hipotesis menunjukkan bahwa kepemilikan manajerial tidak dapat memoderasi pengaruh kebijakan dividen terhadap manajemen laba karena nilai sig 0,401 , nilai ini melebihi $\alpha=5 \%$. Sehingga didapatkan bahwa H8, ditolak. Hal ini menunjukkan bahwa kepemilikan manajerial tidak dapat memoderasi pengaruh terhadap manajemen laba. Kepemilikan manajerial yang diukur berdasarkan kepemilikan saham yang dimiliki direksi tidak mampu mempengaruhi hubungan antara kebijakan dividen dengan manajemen laba pada perusahaan BUMN. Hasil ini tidak sesuai dengan teori agensi dimana kepemilikan manajerial akan mengurangi konflik antara manajemen dengan pemegang saham. Hal ini mungkin disebabkan pemegang saham manajerial lebih memilih 
mendapatkan kompensasi (gaji, tunjangan, dan bonus) dibandingkan dengan dividen yang dibagikan perusahaan (Gustian \& Mutasowifin, 2015). Dividen yang tidak dibagi akan menjadi laba ditahan yang digunakan melakukan ekspansi untuk meningkatkan laba, dan dengan demikian akan dapat meningkatkan kompensasi untuk manajemen. Sehingga dapat disimpulkan bahwa kepemilikan manajerial tidak mampu memoderasi hubungan kebijakan dividen terhadap manajemen laba.

\section{KESIMPULAN}

Adapun hasil analisis dan pembahasan telah dipaparkan sebelumnya, dapat ditarik kesimpulan sebagai berikut:

1. Profitabilitas tidak berpengaruh signifikan terhadap manajemen laba.

2. Leverage berpengaruh negatif signifikan terhadap manajemen laba.

3. Ukuran perusahaan tidak berpengaruh terhadap manajemen laba.

4. Kebijakan dividen tidak berpengaruh terhadap manajemen laba.

5. Kepemilikan manajerial tidak mampu memoderasi hubungan profitabilitas terhadap manajemen laba.

6. Kepemilikan memoderasi hubungan leverage terhadap manajemen laba.

7. Kepemilikan manajerial tidak mampu memoderasi hubungan ukuran perusahaan terhadap manajemen laba.

8. Kepemilikan manajerial tidak mampu memoderasi hubungan kebijakan dividen terhadap manajemen laba.

Berdasarkan hasil dari penelitian ini, saran yang diberikan adalah sebagai berikut:

1. Penelitian ini menemukan bahwa leverage dapat menekan manajemen untuk tidak melakukan manajemen laba. Hasil ini dapat digunakan sebagai refrensi untuk pihak eksternal perusahaan khususnya pihak perbankan untuk melakukan pengawasan yang ketat terkait pemberian dana pinjaman kepada emiten dengan tingkat leverage tinggi. Pengawasan yang selektif akan menghambat fleksibilitas manajemen sehingga akan mengurangi kesempatan bagi agen (manajemen) untuk bertindak oportunistik.

2. Penelitian mendatang diharapkan menggunakan proksi selain total aset untuk mengukur besarnya perusahaan BUMN. Dilihat dari analisis deskriptif perusahaan BUMN hanya memiliki rata-rata return on asset sebesar $5 \%$. Hal ini mengindikasikan aset yang besar belum tentu menghasilkan laba yang tinggi. Sehingga untuk penelitian selanjutnya dalam mengukur suatu perusahaan dapat menggunakan proksi lain seperti total pendapatan, total karyawan perusahaan, total ekuitas, nilai pasar ekuitas.

\section{REFERENSI}

Agustia, D. (2013). Pengaruh Faktor Good Corporate Governance, Free Cash Flow, dan Leverage Terhadap Manajemen Laba. Jurnal Akuntansi Dan Keuangan, 15(1), 27-42. https://doi.org/DOI: 10.9744/jak.15.1.27-42

Aljana, B. T., \& Purwanto, A. (2017). Pengaruh Profitabilitas, Struktur Kepemilikan Dan Kualitas Audit Terhadapmanajemen Laba (Studi pada Perusahaan Manufaktur yang Terdaftar di Bursa Efek Indonesia Tahun 20132015). Diponegoro Journal of Accounting, 6(3), 1-15.

Dahayani, N. K. S., Budiartha, I. K., \& Suardikha, I. M. S. (2017). Pengaruh Kebijakan Dividen Pada Manajemen Laba Dengan Good Corporate Governance Sebagai Moderasi. EJurnal Ekonomi Dan Bisnis Universitas Udayana, 6(4), 1395-1424.

Davis, J. H., Schoorman, F. D., \& Donaldson, L. (1997). Toward a Stewardship Theory of Management. The Academy of Management Review, 22(1), 20-47. https://doi.org/DOI: $10.2307 / 259223$

Dewi, P. E. P., \& Wirawati, N. G. P. (2019). E-Jurnal Akuntansi Universitas Udayana Pengaruh Leverage Terhadap Manajemen Laba Dengan Corporate Governance Sebagai Variabel Pemoderasi. E-Jurnal Akuntansi Universitas Udayana, 27(1), 505-533. DOI: https://doi.org/10.24843/EJA.2019.v27.i01.p1 9

Fandriani, V., \& Tunjung, H. (2019). Pengaruh Profitabilitas, Leverage, Ukuran Perusahaan, Dan Kualitas Audit Terhadap Manajemen Laba. Jurnal Multiparadigma Akuntansi, 1(2), 505-5014.

Fauzia, M. (2019). Laporan Keuangan 2018 Direvisi, Garuda Indonesia Rugi Rp 2,45 Triliun. https://money.kompas.com/read/2019/07/26/1 11246526/laporankeuangan-2018-direvisigaruda-indonesia-rugi-rp-245-triliun?page=all

Gustian, N., \& Mutasowifin, A. (2015). Analisis Pengaruh Kepemilikan Manajerial terhadap Kebijakan Pendanaan dan Dividen. Jurnal Manajemen Dan Organisasi, 6(2), 163-175.

Hasty, A. D., \& Herawaty, V. (2017). Pengaruh struktur kepemilikan, leverage , profitabilitas dan kebijakan dividen terhadap manajemen laba dengan kualitas audit sebagai variabel moderasi. Media Riset Akuntansi, Auditing \& Informasi, 17(1), 1-16.

Hps. (2019). Restatement \& Batal Kontrak Mahata, Saham Garuda Amblas. 
https://www.cnbcindonesia.com/market/20190 726120159-17-87792/restatement-batalkontrak-mahata-saham-garuda-amblas

Jannah, A. M., \& Mildawati, T. (2017). Pengaruh Aset Perusahan, Pajak Penghasilan, dan Mekanisme Corporate Governance Terhadap Mananjemen Laba. Jurnal Ilmu Dan Riset Akuntansi, 6(September), 1-19.

Jensen, M. C., \& Meckling, W. H. (1976). Theory Of The Firm : Managerial Behavior, Agency Costs And Ownership Structure. Journal of Finance Economics, 3, 305-360.

Lestari, E., \& Murtanto. (2017). Pengaruh Efektivitas Dewan Komisaris Dan Komite Audit, Struktur Kepemilikan, Kualitas Audit terhadap Manajemen Laba. Jurnal Media Riset Akuntansi, Auditing \& Informasi, 17(2), 97$116 . \quad$ https://doi.org/Doi : http://dx.doi.org/10.25105/mraai.v17i2.2063

Peraturan Otoritas Jasa Keuangan Nomor 29/POJK.04/2016.

PSAK No. 1 Tentang Laporan Keuangan Revisi 2015.

Purnama, D. (2017). Pengaruh Profitabilitas, Leverage, Ukuran Perusahaan, Kepemilikan Institusional Dan Kepemilikan Manajerial Terhadap Manajemen Laba. JRKA, 3(1), 1-14.

Putri, I. G. A. M. A. D. (2012). Pengaruh Kebijakan Dividen Dan Good Corporate Governance Terhadap. Buletin Studi Ekonomi, 17(2), 157171.

Qallap, K. daifallah hmoud Al, University, A. B. A., \& College, Z. U. (2014). Earning Management in Jordanian public Shareholding Service Companies and Influential Factors. Research Journal of Finance and Accounting, 5(12), 70-
81.

Raharjo, E. (2007). Teori Agensi dan Teori Stewrship dalam Perspektif Akuntansi. Fokus Ekonomi, 2(1), 37-46.

Ross, S. (1977). The Determination of Financial Structure: The Incentive Signaling Approach. Bell Journal of Economics and Management Science, 8(1), 23-40. https://doi.org/DOI: $10.2307 / 3003485$

Selahudina, N. F., Zakaria, N. B., Sanusi, Z. M., \& Budsaratragoon, P. (2014). Monitoring financial risk ratios and earnings management : evidence from Malaysia and Thailand. Procedia - Social and Behavioral Sciences, 145, 51-60. https://doi.org/10.1016/j.sbspro.2014.06.010

Sulistiawan, D., Januarsi, Y., \& Alvia, L. (2011). Creative Accounting: Mengungkap Manajemen Laba dan Skandal Akuntansi. Salemba Empat.

Sulistyanto, S. (2008). Manajemen Laba: Teori dan Model Empiris. Grasindo.

Wirawati, N. G. P., Putri, I. G. A. M. A. D., \& Wirasedana, I. W. P. (2018). Pengaruh Kebijakan Dividen, Kompensasi, Dan Leverage Pada Manajemen Laba Di Perusahaan Manufaktur. Jurnal KRISNA: Kumpulan Riset Akuntansi, 10(1), 32-40. https://doi.org/DOI: http://dx.doi.org/10.22225/kr.10.1.709.32-40

Wiyadi, Trisnawati, R., Sasongko, N., \& Fauzi, I. (2015). The Effect of Asymmetry , Firm Size, Leverage, Profitability and Employee Stock Ownership on Earning Management With Accrual Model. International Journal of Business, Economics and Law, 8(2), 21-30. 